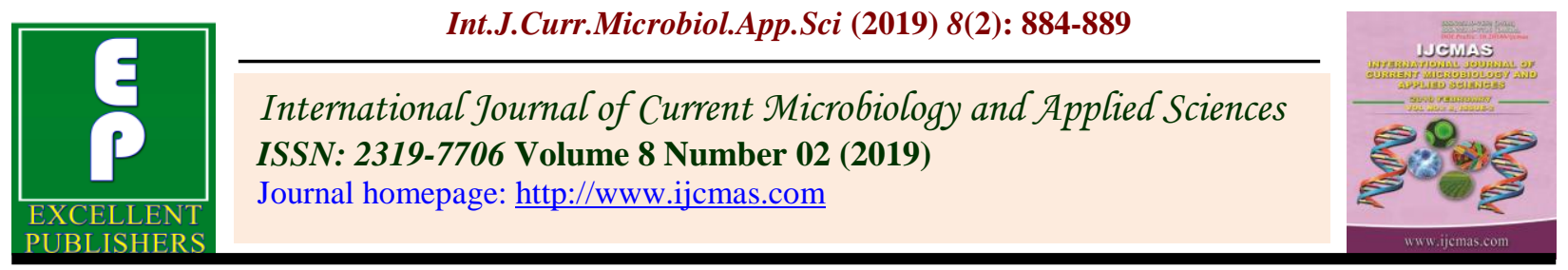

\title{
Effect of Hardening Media and Different Cross Combinations on Leaf Gas Exchange Parameters of in vitro Cultured Citrus Plantlets
}

\author{
Anjali Soni $^{1}{ }^{*}$, A.K. Dubey ${ }^{1}$, R.M. Sharma ${ }^{1}$, O.P. Awasthi ${ }^{1}$ and Bharadwaj Chellapilla ${ }^{2}$ \\ ${ }^{1}$ Division of Fruits and Horticultural Technology, ${ }^{2}$ Division of Genetics, \\ ICAR-Indian Agricultural Research Institute, New Delhi-110012, India \\ *Corresponding author
}

A B S T R A C T

\begin{tabular}{|l|}
\hline Ke y word s \\
$\begin{array}{l}\text { Hardening media, in } \\
\text { vitro, Cocopeat and } \\
\text { leaf gas exchange }\end{array}$ \\
\hline Article Info \\
\hline $\begin{array}{l}\text { Accepted: } \\
\text { 10 January } 2019 \\
\text { Available Online: } \\
\text { 10 February } 2019\end{array}$ \\
\hline
\end{tabular}

The present investigation entitled as "Effect of hardening media and different cross combinations on physiological parameters of in vitro cultured citrus plantlets" was carried out in the Division of Fruits and Horticultural Technology, ICAR-IARI, New Delhi. The experiment consisted of embryo rescued plantlets from cross pollination (control pollination) and open pollination (uncontrolled pollination) and two hardening media HM1(Coco peat: Perlite: Vermiculite, 1:1:1) and HM2 (Coco peat: Perlite: Vermiculite, 2:1:1). The results revealed that the progenies of ALC-2 x Kagzi Kalan had highest values of leaf gas exchange traits like internal $\mathrm{CO}_{2}$ concentration $(C i)$, transpiration rate $(E)$, stomatal conductance $\left(g_{s}\right)$ and photosynthesis rate $(A)$ which was followed by progenies of PusaUdit x KagziKalan. However, it was least in progenies of Troyer citrange (Open pollinated). Considering the hardening media, there was a general trend of the higher leaf gas exchange in the HM1media (Coco peat: Perlite: Vermiculite, 1:1:1) compare to HM2 media (Coco peat: Perlite: Vermiculite, 2:1:1).

\section{Introduction}

One of the major impediments to the success of micropropagation is the low survival rates and poor growth of tissue culture derived plantlets either during the acclimatization phase or at transfer to field conditions (Moraes et al., 2004). Therefore, commercial utilization of micropropagation requires a successful acclimatization (Deccetti et al., 2008; Dobránszki et al., 2010). In the whole process of successful plantlet transfer from in vitro to ex vitro conditions is difficult because of significant environmental differences (Hazarika, 2003). Pospíšilová et al., 2007 reported that plantlets raisedin vitro are exposed to diminished gas exchange, high air humidity, low irradiance, and use of sugar as energy source, which could cause inhibition of photosynthesis, abnormal stomatal structure, and generally could lead to high plantlet mortality during acclimatization. Therefore, acclimatization to new environmental conditions, such as increased irradiance and low air humidity, requires that plants undergo physical and anatomical 
changes by Hazarika (2006). Leaf conductance and net photosynthesis were positively correlated with water status (relative water content) of tissue- cultured shoots and plantlets, and that acclimatization was associated with a reduction in leaf conductance and transpiration as reported by Díaz- Pérez et al., (1995). The E is generally high at the beginning of acclimatization but decreases gradually after adaptation to the external environment (Pospíšilová et al., 1999; Chaari-Rkhis et al., 2011).

In tissue culture raised plants there are several anatomical and morphological and physiological changes used to occur. The changes in the physiology of the plantlets are generally characterized by measuring the leaf gas exchange parameters like internal $\mathrm{CO}_{2}$ concentration $(\mathrm{Ci})$, transpiration rate $(E)$, stomatal conductance $\left(g_{s}\right)$ and photosynthesis rate $(A)$. However, limited information are available on physiological changes and plant performance during acclimatization in citrus fruit crops. So Keeping in view of all these facts, after primary hardening of in vitro raised plantlets under controlled condition, plantlets were shifted in the green colour shade net house (50\% shade) and the influence of different parents and hardening media on leaf gas exchange parameters were studied.

\section{Materials and Methods}

The present experiment was carried out in the citrus hybridization experimental field at the main orchard of Division of Fruits and Horticultural Technology, ICAR-Indian Agricultural Research Institute, New Delhi.

\section{Plant material}

Embryo rescued plantlets from cross pollination (control pollination) and open pollination (uncontrolled pollination) were utilized for this study. Details of plant materials used in this experiment are given in Table 1.

\section{Media composition}

The hardening media HM1: Coco peat: Perlite: Vermiculite $(1: 1: 1)$ and HM2: Coco peat, Perlite and Vermiculite $(2: 1: 1)$ were used for hardening purpose of in vitro raised seedlings.

\section{Plantlets in shade net house}

The plantlets raised through embryo rescue of control pollinated as well as open pollinated seedlings of various citrus species were acclimatized using above mentioned growing (potting) media. After primary hardening under controlled condition in different media, plantlets were shifted in the green colour shade net house (50\% shade) (Plate 1), experiencing the following climatic condition: relative humidity- $84-90 \%$, maximum temperature- $36.0^{\circ} \mathrm{C}$ and minimum temperature $-27.0^{\circ} \mathrm{C}$.

The plantlets have been kept for 4 days with perforated polythene cover, thereafter covering of the plantlets were removed, and plantlets were allowed to acclimatize under natural environmental conditions. The plantlets were irrigated with water containing soluble NPK (10 g/l) as and when required depending upon the rain.

\section{Physiological parameters}

The leaf gas exchange traits like internal $\mathrm{CO}_{2}$ concentration $(\mathrm{Ci})$, transpiration rate $(E)$, stomatal conductance $\left(g_{s}\right)$ and photosynthesis rate $(A)$ were measured on fully mature three leaves of plantlets as per treatments of potting media and cross combinations using IRGA (LI- Cor 6200 LI-Cor Bioscience, Lincoln NE USA). All the data were recorded in morning hour between 9.00 to 11.00 A.M. 


\section{Statistical analysis}

Experiment was conducted in factorial arrangement with three replications and analysis of variance (ANOVA) was calculated using SAS software (SAS 9.3 USA INC.) followed by Duncan multiple range test at $\mathrm{P} \leq$ $0.05)$.

\section{Results and Discussion}

Both parent and media had significant effect on most of the gas exchange traits (Table 2). Regardless of hardening media, progenies of ALC-2 x Kagzi Kalan had highest values of $C i, E, g s$ and $A$ which was followed by progenies of PusaUdit x KagziKalan. For all gas exchange traits. However, it was least in progenies of Troyer citrange (OP). Considering the hardening media alone, there was a general trend of the higher leaf gas exchange in the HM1 media compare to HM2 media. Earlier finding of Pospísilová et al., (1999) reported that compared to in vitro plants, transplanted plants had a higher water status and higher leaf conductance and net photosynthesis and there was also an increase in the leaf area ratio (leaf area to plant biomass ratio) after they were transplanted which might have contributed to the higher net assimilation rate in transplanted compared to in vitro plants (Fig. 1).

Parent and hardening media jointly too exhibited significant differences on leaf gas exchange parameters in the shade net house
(Table 3). Variable results were noticed with regard to different leaf gas exchange traits. Progenies of Troyer citrange (OP) had highest values of $C i\left(353.33 \mu \mathrm{mol} \mathrm{mol}{ }^{-1} \mathrm{~m}^{-2} \mathrm{~s}^{-1}\right)$ in HM1 medium followed by progenies of Cleopatra mandarin $\mathrm{x}$ Traoyercitrange in HM2 medium. The lowest $C i$ was recorded in the progenies of Pusa Udit (OP) in HM1 medium. Notwithstanding, greatest $E(1.23 \mathrm{~m}$ mol $\mathrm{H}_{2} 0 \mathrm{~m}^{-2} \mathrm{~s}^{-1}$ ) was measured in progenies of Pusa Udit (OP) when grown in HM2 medium which was not differed significantly with Cleopatra $\mathrm{x}$ Troyer citrange progenies (1.09) in HM2 medium likewise progenies of Cleopatra mandarin $\mathrm{x}$ Troyer citrange too exhibited highest values of $g s$ $\left(0.040 \mathrm{mmol} \mathrm{m}^{-2} \mathrm{~s}^{-1}\right)$ in HM2 medium which showed statistical similarity with those of Pusa Udit (OP) in HM2 medium, ALC-2 x Kagzi Kalan progenies in HM1 medium, PusaUdit x KagziKalan Progenies in HM2 medium, progenies of ALC-2 (OP) in either medium. However, progenies of Pusa Udit (OP) had highest values of $A$ in HM2 medium followed by progenies of similar treatment in HM1 medium and Progenies of ALC- $x$ Kagzi Kalan in HM2 medium. Estrada-Luna et al., (2001) observed that after initial ex vitro transplanting micro propagated chile ancho pepper (Capsicum annuum L. cv. San Luis) plantlets experienced water deficit leaf wilting and reduced relative water content (RWC), which corresponded with reduced stomatal conductance $(g s)$ and transpiration $(E)$, and an increase in stomatal resistance ( $\mathrm{rs}$ ).

Table.1 Citrus genotypes transferred in shade net house

\begin{tabular}{|l|l|l|}
\hline Seedling type & Female parent $(+)$ & Male parent $\left({ }^{\wedge}\right)$ \\
\hline \multirow{3}{*}{ Cross pollinated } & ALC-2 & Kagzi Kalan \\
\cline { 2 - 3 } & Pusa Udit & Kagzi Kalan \\
\cline { 2 - 3 } Open pollinated & Cleopatra mandarin & Troyer citrange \\
\hline \multirow{2}{*}{} & ALC-2 & Unknown \\
\hline & Pusa Udit & Unknown \\
\cline { 2 - 3 } & Troyer citrange & Unknown \\
\hline
\end{tabular}


Table.2 Mean effect of crosses and hardening media on different leaf gas exchange parameters in the shade net house

\begin{tabular}{|c|c|c|c|c|}
\hline Treatment & $\begin{array}{l}\text { Leaf internal } \mathrm{CO}_{2} \\
\text { conc. }(\mu \mathrm{molmol} \\
\left.{ }^{1} \mathrm{~m}^{-2} \mathrm{~s}^{-1}\right)\end{array}$ & 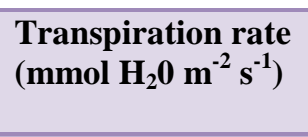 & 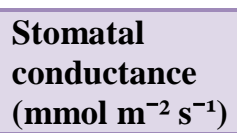 & $\begin{array}{l}\text { Photosynthesis } \\
\text { rate } \\
\left(\mu \mathrm{mol} \mathrm{CO}_{2} \mathrm{~m}^{-2} \mathrm{~s}^{-1}\right)\end{array}$ \\
\hline ALC-2 X KagziKalan & $345.50^{\mathrm{a}}$ & $0.92^{\mathrm{a}}$ & $0.02^{\mathrm{a}}$ & $3.08^{\mathrm{a}}$ \\
\hline PusaUdit X KagziKalan & $323.66^{b}$ & $0.78^{\mathrm{b}}$ & $0.02^{\mathrm{ba}}$ & $2.30^{\mathrm{b}}$ \\
\hline Cleopatra X Troyer citrange & $323.33^{\mathrm{b}}$ & $0.62^{\mathrm{c}}$ & $0.02^{\text {ba }}$ & $1.54^{\mathrm{c}}$ \\
\hline ALC-2 (OP) & $305.83^{\mathrm{c}}$ & $0.61^{\mathrm{c}}$ & $0.02^{\mathrm{ba}}$ & $1.47^{\mathrm{d}}$ \\
\hline Pusa Udit (OP) & $253.00^{d}$ & $0.51^{\mathrm{d}}$ & $0.02^{\mathrm{ba}}$ & $1.46^{\mathrm{d}}$ \\
\hline Troyer citrange (OP) & $234.33^{\mathrm{e}}$ & $0.30^{\mathrm{e}}$ & $0.01^{\mathrm{b}}$ & $1.17^{\mathrm{e}}$ \\
\hline \multicolumn{5}{|l|}{ Hardening media } \\
\hline HM1 & $313.61^{\mathrm{a}}$ & $0.74^{\mathrm{a}}$ & $0.02^{\mathrm{a}}$ & $1.94^{\mathrm{a}}$ \\
\hline HM2 & $281.61^{\mathrm{b}}$ & $0.50^{b}$ & $0.01^{\mathrm{b}}$ & $1.73^{\mathrm{b}}$ \\
\hline \multicolumn{5}{|l|}{ LSD $(P \leq 0.05)$} \\
\hline Cross & 3.02 & 0.07 & 0.00 & 0.03 \\
\hline Growing media & 1.74 & 0.04 & 0.00 & 0.01 \\
\hline
\end{tabular}

*OP; Open pollinated; *Each data represents the mean value of three samples. Values are representing different letters significant at $\mathrm{P} \leq 0.05$ (THST).

Table.3 Effect of hardening media on leaf gas exchange parameters of different crosses and open pollinated zygotic seedling in the shade net house

\begin{tabular}{|c|c|c|c|c|}
\hline Treatment & $\begin{array}{l}\text { Leaf internal } \mathrm{CO}_{2} \text { conc. } \\
\left(\mu \mathrm{molmol}^{-1} \mathrm{~m}^{-2} \mathrm{~s}^{-1}\right)\end{array}$ & $\begin{array}{l}\text { Transpiration rate } \\
\left(\mathrm{mmol} \mathrm{H}_{2} \mathbf{O ~ m}^{-2} \mathrm{~s}^{-1}\right)\end{array}$ & 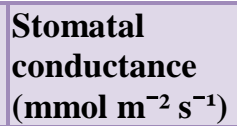 & $\begin{array}{l}\text { Photosynthesis } \\
\text { rate } \\
\left(\mu \mathrm{mol} \mathrm{CO}_{2} \mathrm{~m}^{-2} \mathrm{~s}^{-1}\right)\end{array}$ \\
\hline \multicolumn{5}{|c|}{ ALC-2 X KagziKalan } \\
\hline HM1 & $225.33^{\mathrm{e}}$ & $0.20^{\mathrm{e}}$ & $0.03^{\text {bac }}$ & $1.83^{\mathrm{e}}$ \\
\hline HM2 & $280.67^{d}$ & $0.40^{\mathrm{d}}$ & $0.02^{c}$ & $2.77^{\mathrm{c}}$ \\
\hline \multicolumn{5}{|c|}{ PusaUdit X KagziKalan } \\
\hline HM1 & $324.00^{c}$ & $0.69^{b}$ & $0.01^{\mathrm{c}}$ & $1.53^{\mathrm{f}}$ \\
\hline HM2 & $323.33^{\mathrm{c}}$ & $0.53^{\mathrm{cbd}}$ & $0.030^{\text {bac }}$ & $1.40^{\mathrm{g}}$ \\
\hline \multicolumn{5}{|c|}{ Cleopatra X Troyer citrange } \\
\hline HM1 & $277.33^{d}$ & $0.47^{\mathrm{cd}}$ & $0.01^{\mathrm{c}}$ & $1.14^{\mathrm{i}}$ \\
\hline HM2 & $334.33^{\mathrm{b}}$ & $1.09^{\mathrm{a}}$ & $0.040^{\mathrm{a}}$ & $1.95^{\mathrm{d}}$ \\
\hline \multicolumn{5}{|l|}{ ALC-2 (OP) } \\
\hline HM1 & $324.33^{c}$ & $0.62^{\mathrm{cb}}$ & $0.036^{\text {ba }}$ & $1.10^{\mathrm{i}}$ \\
\hline HM2 & $322.33^{c}$ & $0.62^{\mathrm{cb}}$ & $0.026^{\text {bac }}$ & $1.25^{\mathrm{h}}$ \\
\hline \multicolumn{5}{|l|}{ Pusa Udit (OP) } \\
\hline HM1 & $185.33^{\mathrm{e}}$ & $0.62^{\mathrm{cb}}$ & $0.01^{\mathrm{c}}$ & $2.96^{\mathrm{b}}$ \\
\hline HM2 & $283.33^{d}$ & $1.23^{\mathrm{a}}$ & $0.04^{\mathrm{a}}$ & $3.22^{\mathrm{a}}$ \\
\hline \multicolumn{5}{|c|}{ Troyer citrange (OP) } \\
\hline HM1 & $353.33^{\mathrm{a}}$ & $0.41^{\mathrm{d}}$ & $0.026^{\mathrm{bc}}$ & $1.86^{\mathrm{e}}$ \\
\hline HM2 & $337.67^{b}$ & $0.61^{\mathrm{cb}}$ & $0.020^{\text {bac }}$ & $1.08^{\mathrm{i}}$ \\
\hline LSD $(P \leq 0.05)$ & 7.50 & 0.17 & 0.017 & 0.07 \\
\hline
\end{tabular}

$*$ OP; Open pollinated; *Each data represents the mean value of three samples. Values are representing different letters significant at $\mathrm{P} \leq 0.05$ (THST). 
Fig.1 In vitro raised seedlings of different crosses in the shade net house

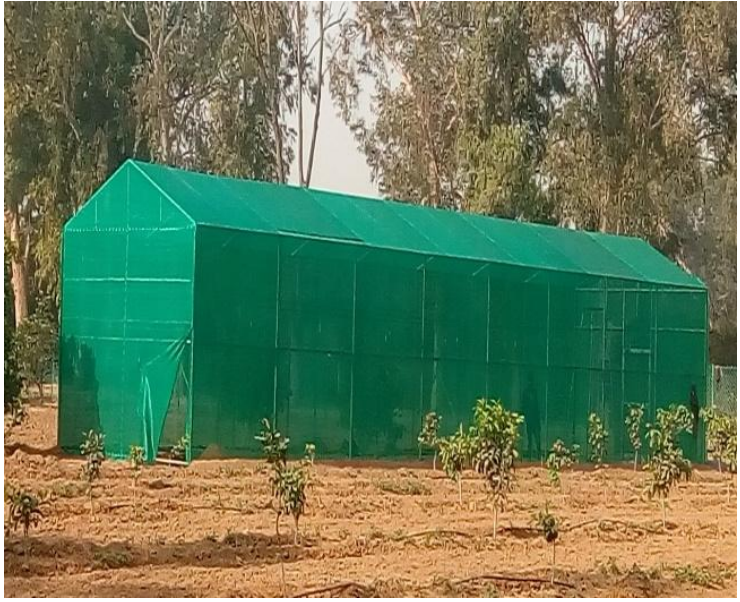

During acclimatization, RWC, $g s, E$, and $A$ were significantly lower two days after transplanting. However, within 6 days after transplanting, plantlets recovered and became photoautotrophic attaining high $A, g s$, and $E$.

In conclusion, the experimental results suggested that the progenies of controlled cross combination ALC- 2 x Kagzi Kalan had highest values of leaf internal $\mathrm{CO}_{2}$ concentration $(\mathrm{Ci})$, transpiration rate $(E)$, stomatal conductance $(g s)$ and photosynthesis rate $(A)$ however the open pollinated progenies of Troyer citrange recorded the lowest.There was a general trend of the higher leaf gas exchange in the HM1 media (Coco peat: Perlite: Vermiculite, $1: 1: 1)$ compare to HM2 media(Coco peat: Perlite: Vermiculite, 2:1:1).

\section{References}

Chaari-Rkhis, A., Maalej M., Drira, N. and Standardi, A. (2011). Micropropagation of olive tree (Olea europaea L.) cv. 'Oueslati'. Turkish Journal of Agriculture and Forestry, 35: 403-412.

Chandra, S., Bandopadhyay, R., Kumar, V. and Chandra, R. (2010). Acclimatization of tissue cultured

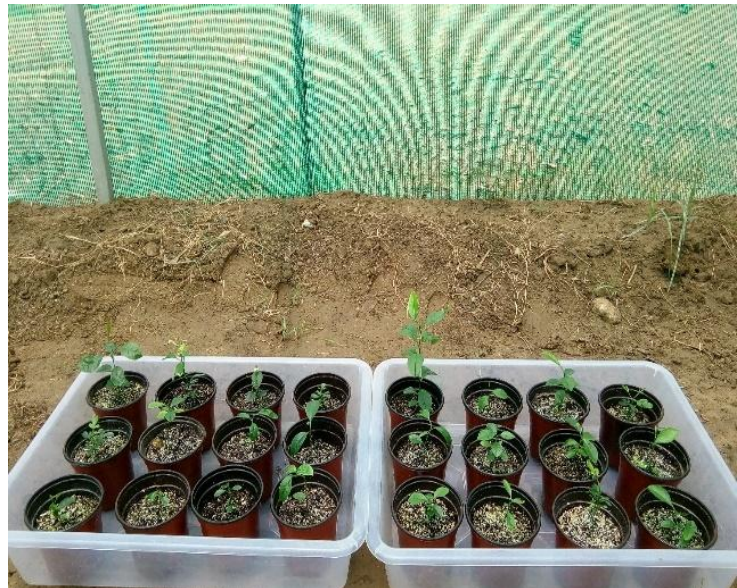

plantlets: from laboratory to land. Biotechnology Letters, 32: 1199-1205.

Deccetti, S.F.C., Soares, A.M., Paiva, R. and De Castro, E.M. (2008). Effect of the culture environment on stomatal features, epidermal cells and water loss of micropropagated Annonaglabra L. plants. Scientia Horticulture, 117: 341344.

Diaz-Perez, J, C., Sutter, E. G. and Shacket, K. A. (1995). Acclimatization and subsequent gas exchange, water relations, survival and growth of microcultured apple plantlets. Physiology Planatarum, 95(2): 225332.

Dobránszki, J. and Teixeira da Silva, J.A. (2010). Micro propagation of apple: A review. Biotechnology Advances, 28: 462-488.

Estrada-Luna, A.A., Davies, F.T. and Egilla, J.N. (2001). Physiological changes and growth of micropropagated Chile ancho pepper plantlets during acclimatization and postacclimatization. Plant Cell Tissue and Organ Culture, 66: 17-24.

Hazarika B.N. (2003). Acclimatization of tissue-cultured plants. Current Science, 85: 1704-1712.

Hazarika, B.N. (2006). Morphophysiological 
disorders in vitro culture of plants. Scientia Horticulture, 108: 105-120.

Moraes, R. M., De Andrade, Z., Bedir, E., Dayan, F. E., Lata, H., Khan, I. and Pereira, A. M. (2004). Arbuscular mycorrhiza improves acclimatization and increases lignancontent of micro propagated mayapple (Podophyllum peltatum L.). Plant Science, 166(1): 2329.

Pospíšilová, J., Synková, H., Haisel, D. and
Semorádová, Š. (2007). Acclimation of plantlets to ex vitro conditions: effects of air humidity, irradiance, $\mathrm{CO}_{2}$ concentration and abscisic acid. Acta Horticulture, 748: 29-38. Pospíšilová, J., Tichá, I. and Kadleček, P. (1999). Acclimatization of micropagated plants to $e x$ vitro conditions. Biologia

\section{How to cite this article:}

Anjali Soni, A.K. Dubey, R.M. Sharma, O.P. Awasthi and Bharadwaj Chellapilla. 2019. Effect of Hardening Media and Different Cross Combinations on Leaf Gas Exchange Parameters of in vitro Cultured Citrus Plantlets. Int.J.Curr.Microbiol.App.Sci. 8(02): 884-889.

doi: https://doi.org/10.20546/ijcmas.2019.802.100 